\title{
Quality and shelf life of sliced root of Platycodon grandiflorum treated by ozon-microbubble-heat shock
}

\author{
Kyung Min Park ${ }^{1}$, Ji Young Lee ${ }^{2}$, So-Ra Min², Moon-Cheol Jeong ${ }^{2}$, \\ Minseon $\mathrm{Koo}^{1,2 *}$ \\ ${ }^{1}$ Department of Food Biotechnology, Korea University of Science \& Technology, Daejoen 34113, Korea \\ ${ }^{2}$ Department of Food Storage and Distribution System, Korea Food Research Institute, Gyeonggi 13539, Korea
}

\section{오존-마이크로버블열수 처리한 세절 도라지의 품질 및 저장성}

\author{
박경민 $^{1} \cdot$ 이지영 ${ }^{2} \cdot$ 민소라 $^{2} \cdot$ 정문철 $^{2} \cdot$ 구민선 $^{1,2 *}$ \\ ${ }^{1}$ 한국과학기술연합대학원대학교 식품생명공학과, ${ }^{2}$ 한국식품연구원 저장유통연구단
}

\begin{abstract}
The quality and shelf life of sliced root of Platycodon grandiflorum (Doraji) treated by ozon-microbubble-heat shock (OMH) were investigated by combining modified-atmosphere packaging [MAP, $\left(50 \% \mathrm{O}_{2}+15 \% \mathrm{CO}_{2}+35 \%\right.$ $\mathbf{N}_{2}$ )]. The study was based on microbiological (total viable bacteria, fungi, Enterobacteriaceae and coliforms numbers), physicochemical and sensory changes. OMH treatment was effective in reducing microbial populations of the sliced Doraji, especially Enterobacteriaceae and coliforms reduced by 2 log CFU/g. However OMH-MAP treatment remained the aerobe and fungi numbers. Regarding the color, OMH-MAP delayed the change of Hunter $b^{*}$ and the sliced Doraji by OMH-MAP treatment exhibited lower decrease of flavor and overall acceptability compared to those by polypropylene packaging after tap water treatment (Control). The $\mathrm{OMH}$ and $50 \% \mathrm{O}_{2}+15 \% \mathrm{CO}_{2}$ MAP treatment gave better sensory quality and extended shelf-life for sliced Doraji ( $\sim 3$ days longer shelf-life than Control). Flavor was significantly related to overall acceptability at both Control and OMH-MAP, whereas total coliforms prevalence was associated with overall acceptability at only OMH-MAP. Therefore microbubble-heat shock treatment may improve microbial safety and sliced Doraji by OMH treatment can stored under $50 \% \mathrm{O}_{2}+15 \% \mathrm{CO}_{2}$ treatment for up to 7 days. Thus, OMH and MAP treatment may be used in maintaining the storage quality and marketability of sliced Doraji.
\end{abstract}

Key words : Platycodon grandiflorum root, microbubble, modified atmosphere packaging, storage quality

\section{서 론}

신선편이 농산물은 건강식품에 대한 소비자의 관심으로 빠른 소비 증가 추세를 나타내고 있다. 특히 급식 및 외식 업체에서는 조리과정이나 가공과정에서 소요되는 인력이 나 시간 등을 절감하기 위한 방안으로서, 세척, 다듬기, 절

*Corresponding author. E-mail : minsk@kfri.re.kr Phone : 82-31-780-9161, Fax : 82-31-709-9876

Received 19 April 2016; Revised 9 June 2016; Accepted 4 July 2016

Copyright (c) The Korean Society of Food Preservation. All rights reserved.
단, 포장 등의 가공 과정을 거친 농산물의 사용이 증가하고 있는 추세이다(1). 신선편이 농산물은 조리 시간의 절약과 간편성이라는 장점을 가지고 있지만 세척, 박피, 절단 등의 작업으로 세포벽이 파괴되면서 호흡, 갈변, 조직연화 등 물리화학적 변화가 급속히 진행되며, 미생물의 오염 가능 성도 증가하므로 급식 및 외식업체에서 오염된 농산물의 사용으로 대형 식중독 사고를 일으킬 수 있다 $(2,3)$. 지금까 지의 신선편이 농산물에 관한 연구는 제조공정 및 유통 조건의 표준화(4), 저장 온도 및 포장에 따른 최소가공처리 채소류의 품질 특성 $(5,6)$, 세척 및 저장에 따른 신선편이 엽채류의 저장 중 품질 변화 평가 등 $(7,8)$ 에 대한 연구가 수행되었다. 대부분의 연구가 포장 방법이나 저장 온도에 
따른 미생물학적 품질평가에 대한 것으로 세척 방법에 따른 신선편이 농산물의 품질 특성 평가에 관한 연구는 부족한 실정이다. 특히 연근, 더덕, 도라지 등과 같은 근채류는 단체 급식에서 많이 쓰이는 식재료임에도 불구하고 연구가 부족 한 실정이다.

도라지(Platycodon grandiflorum)는 섬유질이 풍부하고 암세포 증식 억제 등의 효과로 영양학적 우수성뿐만 아니라 기능학적으로 우수한 식품이다(9). 그러나 다량을 수분을 함유하고 있어 쉽게 변질되고 신선편이 제품으로 가공 시 절단 및 박피 과정 중에 발생하는 조직 손상으로 인하여 호흡 등 생리활성이 높고 보호층이 파괴되어 미생물의 감염 및 증식이 용이하고 갈변 등을 유발하여 제품의 저장성과 품질을 저하시킨다(10). 세절 도라지는 대부분 진공포장한 후 유통되는데 유통 과정 중 포장 내부에 산소가 없고 이산 화탄소가 높게 축적되면서 진공풀림 현상이 나타나 갈변이 발생하거나 휘발성 물질 생성에 의한 이취 등이 발생한다 (11). 따라서 고품질의 세절 도라지를 유통하기 위해서는 품질 변화가 적으면서 선도 유지 기간을 연장할 수 있는 세척 및 포장 조건을 탐색하여 세절 도라지의 저장성을 향상시킬 방안 마련이 필요하다.

마이크로버블은 직경 $50 \mathrm{um}$ 이하의 작은 기포로 물에서 발생시 음전하를 띠어 양전하를 띤 미생물과 정전기력으로 결합을 하여 마이크로버블이 파열할 때 발생되는 하이드록 실 라디칼의 에너지로 살균 효과를 일으키는 것으로 알려져 있다(11). 이 기술은 현재 폐수 처리, 의료, 수산, 반도체분야 등에서 활용되고 있으나, 농식품의 세척 및 살균 시스템 등으로 활용은 아직 초기단계에 있다. 마이크로버블을 활 용한 연구로는 마이크로버블을 처리한 상추의 저장 중 품질 변화(8), 깻잎, 상추, 미니 배추에서 마이크로버블을 이용한 세척 살균 효과(12)에 대한 연구가 있으나, 근채류의 세척 및 살균 처리에 대한 연구는 부족한 실정이다. 이와 함께 열처리는 신선 농산물의 갈변관련 효소인 polyphenol oxidase, peroxidase등을 불활성시킴으로써 갈변을 억제할 뿐만 아니라 미생물 번식을 억제하는데 효과적이다(14). 또한 근채류 특유의 떫은맛 제거와 더불어 식품에 향과 맛을 부여하는 장점을 가진다(15).

따라서 본 연구는 세절 도라지의 품질 저하 억제를 목적 으로 열수와 마이크로버블 처리에 의한 효과를 확인하였고 아울러 선도 연장을 위한 포장 방법으로 고산소고이산화 탄소 가스치환포장(MAP, modified atmosphere packaging) 을 적용하였던 바 그 결과를 보고하고자 한다.

\section{재료 및 방법}

재 료

본 실험에 사용한 도라지는 세절 도라지로서 2015년 12
월 경기도 소재의 신선편이 농산물 가공업체 (주)웰팜넷으 로부터 구매하여 사용하였다. 세척 박피한 도라지는 밀봉 하여 $10^{\circ} \mathrm{C}$ 의 상태를 유지하면서 2 시간 이내에 실험실로 운반하여 실험에 사용하였다.

세 척

세절 도라지는 무세척, 침지, 오존, 오존-마이크로버블열수 등 네가지의 세척 방법을 적용하였다. 침지구는 물을 넣은 세척조(W800×H600×L400 mm/batch)에 3분간 시료를 침지하였으며, 오존 처리구는 $4 \mathrm{ppm}$ 으로 오존을 발생시킨 물에 시료를 5 분간 침지하였다. 오존, 마이크로버블과 열수 병용 처리구(ozon-microbubble-heat shock, $\mathrm{OMH}$ )는 오존 처 리구 시료를 $10 \mu \mathrm{m}$ 이하의 마이크로버블이 발생하고 있는 세척조(Korea EMB Technology Co., Ltd., Incheon, Korea)에 완전히 담가 $55^{\circ} \mathrm{C}$ 에서 1 분간 침지하였다. 각 처리구는 압축 공기를 이용하여 1 분간 탈수하였다.

\section{포장 및 저장}

침지 후 일반포장(Control) 처리구는 $0.4 \mathrm{~mm}$ 두께의 polypropylene 용기 $(210 \mathrm{~mm} \times 139 \mathrm{~mm} \times 46 \mathrm{~mm}$, Da Chem, Hwaseong, Korea)에 $120 \pm 5 \mathrm{~g}$ 씩 담은 후 상부를 열접착 포장 기(KC-0310L, Gumkang Packing Machine, Daegu, Korea)를 사용하여 $0.05 \mathrm{~mm}$ 두께의 polypropylene(PP) 필름으로 밀봉 하였다. 마이크로버블-가스치환 포장(OMH-MAP) 처리구 는 $\mathrm{O}_{2}: \mathrm{CO}_{2}: \mathrm{N}_{2}$ 농도를 $50: 15: 35$ 가 되도록 하여 $\mathrm{PP}$ 필름 (POCKET 60, Tecnovac, San Paolo D'Argon, Bergamo, Italy) 으로 밀봉하였다. 처리구별 시료는 $5 \pm 1{ }^{\circ} \mathrm{C}, 90 \pm 5 \% \mathrm{RH}$ 로 유지되는 저장고에 저장하면서 $4,7,9,10$ 일에 시료를 채취 하여 품질 변화를 분석하였다.

\section{미생물학적 품질 특성}

일반세균, 대장균군, 대장균은 식품공전법에 따라 분석 하였다(16). 무균적으로 시료 $25 \mathrm{~g}$ 을 취한 뒤 $225 \mathrm{~mL}$ 의 멸균된 $0.85 \%$ saline을 넣고 Stomacher ${ }^{\circledR} 400$ circulator (Seward, Inc., London, England)로 $160 \mathrm{rpm}$ 에서 2분간 균질 화 시킨 후 $1 \mathrm{~mL}$ 씩 취하여 $9 \mathrm{~mL}$ 의 $0.85 \%$ saline 에 단계별 희석하였다. 일반세균은 단계별 희석액 $1 \mathrm{~mL}$ 을 Aerobic Count Plate(3M Microbiology, St. Paul, MN, USA)에 접종하 여 $37^{\circ} \mathrm{C}$ 에서 24 시간 배양한 후 생성된 붉은색 집락수에 희석배수를 곱하여 $\log \mathrm{CFU} / \mathrm{g}$ (colony forming unit/g)으로 나타내었다. 대장균군과 대장균은 일반세균과 같은 방법으 로 단계별 희석 후 건조필름배지(Sanita-kun Coliform/E.coli, JNC Corporation, Tokyo, Japan)를 이용하여 $37^{\circ} \mathrm{C}$ 에서 24시 간 배양하였다. 배양 후 대장균군은 청색 또는 청녹색 집락 을 계수하였으며 대장균은 푸른색 집락을 각각 계수하여 $\log \mathrm{CFU} / \mathrm{g}$ 으로 나타내었다. 대장균 의심 집락은 $\mathrm{VITEK}^{\circledR}$ 2 compact(bioMérieux, Marcy l'Etoile, France)를 이용하여 
생화학 동정하여 최종 확인하였다. 효모 및 곰팡이와 같은 진균류는 Cho 등(17)이 언급한 방법에 따라 건조필름법으 로 실시하였고 단계별 희석 후 PYM(Petrifilm ${ }^{\mathrm{TM}}$ Yeast and Mold count plate)을 이용하여 $25^{\circ} \mathrm{C}$ 에서 5 일간 배양한 후 파란색 또는 녹색의 빛깔을 띠거나 다양한 색상과 균체의 크기가 큰 집락을 계수하였다. 장내세균은 Cheon 등(18)의 방법에 따라 단계별 희석 후 Enterobacteriaceae Count Plate (3M Microbiology, St. Paul, MN, USA)에 접종하여 $37^{\circ} \mathrm{C}$ 에 서 24시간 배양하였다. 배양 후 가스를 발생하는 붉은색 균체, 노란색 환을 보이는 붉은색 균체, 가스를 발생하고 노란색 환을 보이는 붉은색 집락을 계수하여 $\log \mathrm{CFU} / \mathrm{g}$ 으 로 나타내었다.

색 도

색도는 Chroma meter(CR-400, Minolta Co., Osaka, Japan) 로 측정하였다. 도라지의 표면을 각각 15 회 반복 측정하여 $\mathrm{L}^{*}$ (명도), a (적색도), $\mathrm{b}^{*}$ (황색도)값을 평균값으로 나타내었 으며, 저장 초기와 색도 차이를 비교하기 위하여 색차(color difference, $\triangle \mathrm{E}$ )를 다음의 식에 따라 계산하였다.

$$
\triangle \mathrm{E}=\left(\triangle \mathrm{L}^{2}+\triangle \mathrm{a}^{2}+\triangle \mathrm{b}^{2}\right)^{1 / 2}
$$

\section{관능평가}

저장 기간별 세절 도라지의 관능평가는 12 명의 전문 패 널을 대상으로 색, 향, 조직감, 종합 기호도로 구분하여 9점 기호척도법(9점, 매우 좋음; 1점, 매우 나쁨)으로 평가하였 다.

\section{통계처리}

실험 분석 결과와 관능검사 결과의 통계분석은 SPSS software(IBM, SPSS Statistics 20, New York, NY, USA)를 이용하여, 일원배치 분산분석(one way ANOVA)을 실시하 였으며, Duncan의 다중범위검정법(Duncan's multiple range test $)$ 으로 유의성 $(\mathrm{p}<0.05)$ 을 검정하였다. 색도, 미생물과 종 합적 관능평가 지수와의 상관관계는 Pearson's correlation 을 사용하였다.

\section{결과 및 고찰}

\section{세척 방법에 따른 미생물학적 품질 특성}

세절 도라지의 세척 방법에 따른 미생물학적 품질 특성 에 대한 결과는 Table 1과 같다. 침지구(Dip)와 오존 처리구 $\left(\mathrm{O}_{3}\right)$ 도라지의 일반세균수는 각각 $7.0 \log \mathrm{CFU} / \mathrm{g}, 6.9 \log$ $\mathrm{CFU} / \mathrm{g}$ 으로 무세척(not treatment, NT) 도라지의 $6.9 \mathrm{log}$ $\mathrm{CFU} / \mathrm{g}$ 과 거의 차이가 없었으나, 오존-마이크로버블-열수 병용 처리구 $(\mathrm{OMH})$ 에서는 $5.4 \log \mathrm{CFU} / \mathrm{g}$ 으로 약 $1 \log$
$\mathrm{CFU} / \mathrm{g}$ 이상 감소하였다(p<0.05). NT의 진균류수는 $3.9 \mathrm{log}$ $\mathrm{CFU} / \mathrm{g}$ 였고, $\mathrm{Dip}$ 과 $\mathrm{O}_{3}$ 처리구도 $3.8 \mathrm{log} \mathrm{CFU} / \mathrm{g}$ 과 $3.4 \mathrm{log}$ $\mathrm{CFU} / \mathrm{g}$ 로 거의 변화가 없었으나, $\mathrm{OMH}$ 처리구는 $1.6 \mathrm{log}$ $\mathrm{CFU} / \mathrm{g}$ 으로 유의적인 감소를 보였다.

Table 1. Effect of different washing methods on various microor ganisms in sliced root of Platycodon grandiflorum

\begin{tabular}{ccccc}
\hline Treatment $^{1)}$ & TVC $^{2)}$ & Fungi & Enterobacteriaceae & Coliforms \\
\hline NT & $6.9 \pm 0.05^{33 b 4)}$ & $3.9 \pm 0.09^{\mathrm{c}}$ & $5.9 \pm 0.07^{\mathrm{b}}$ & $6.0 \pm 0.01^{\mathrm{d}}$ \\
Dip & $7.0 \pm 0.04^{\mathrm{c}}$ & $3.8 \pm 0.04^{\mathrm{c}}$ & $6.6 \pm 0.83^{\mathrm{b}}$ & $5.4 \pm 0.01^{\mathrm{b}}$ \\
$\mathrm{O}_{3}$ & $6.9 \pm 0.03^{\mathrm{bc}}$ & $3.4 \pm 0.24^{\mathrm{b}}$ & $5.6 \pm 0.04^{\mathrm{b}}$ & $5.7 \pm 0.04^{\mathrm{c}}$ \\
$\mathrm{OMH}$ & $5.4 \pm 0.06^{\mathrm{a}}$ & $1.6 \pm 0.16^{\mathrm{a}}$ & $3.7 \pm 0.02^{\mathrm{a}}$ & $3.2 \pm 0.02^{\mathrm{a}}$ \\
\hline p-value & 0.000 & 0.000 & 0.008 & 0.000 \\
\hline
\end{tabular}

${ }^{1)} \mathrm{NT}$, Not treatment; Dip, Tap water ( $\left.3 \mathrm{~min}\right) ; \mathrm{O}_{3}, 4$ ppm Ozon ( $5 \mathrm{~min}$ ); OMH, microbubble and $55^{\circ} \mathrm{C}$ water after $4 \mathrm{ppm}$ ozone $(5 \mathrm{~min})$.

${ }^{2)} \mathrm{TVC}$, total viable bacterial counts.

${ }^{3)}$ Value are mean \pm SE.

4)a-d In a row means followed by different superscripts are significantly different at the $p<0.05$ level.

장내세균은 사람과 동물의 장 속에 기생하는 그람 음성 세균으로 사람에게서 감염을 유발시킬 수 있는 Citrobacter,

Enterobacter, Escherichia, klebsiella, Salmonella, Yersinia 등의 속이 포함된다(19). 유럽에서는 장내세균을 식품 생산 및 가공 공정에서 위생 지표 세균으로 선택하고 있고 과일 또는 야채, 건조 유아식, 낙농 제품, 축산물 도체, 아이스크 림, 분말우유, 난가공품 등 매우 광범위한 식품에서 장내세 균의 기준이 설정되어 있다(20). 그러나 한국에서는 영유아 용 조제분유에 대하여 Enterobacter sakazakii 균의 불검출 이 설정되어 있으나(21) 그 외의 식품에 대해서는 장내세균 의 미생물 기준이 설정되어 있지 않다. 따라서 국내 농산물 의 품질을 예측하기 위한 위생지표로서 장내세균을 활용하 기위한 기초자료 마련을 위하여 장내세균의 오염도를 확인 하였다. 본 연구에서 장내세균수는 NT 처리구 $5.9 \mathrm{log}$ $\mathrm{CFU} / \mathrm{g}$, Dip 처리구 $6.6 \log \mathrm{CFU} / \mathrm{g}, \mathrm{O}_{3}$ 처리구 $5.6 \mathrm{log} \mathrm{CFU} / \mathrm{g}$, $\mathrm{OMH}$ 처리구 $3.7 \log \mathrm{CFU} / \mathrm{g}$ 로 나타나 $\mathrm{OMH}$ 처리가 장내세 균 제어에도 높은 효과를 보였다 $(\mathrm{p}<0.05)$.

대장균군도 NT, Dip, $\mathrm{O}_{3}$ 처리구는 거의 변화가 없었으나, $\mathrm{OMH}$ 처리구는 $3.2 \log \mathrm{CFU} / \mathrm{g}$ 로 $2.8 \log \mathrm{CFU} / \mathrm{g}$ 의 감소를 보였다 $(\mathrm{p}<0.05)$. 모든 도라지 처리구에서 대장균은 검출되 지 않았다. 이와 같은 결과는 Lee 등(13)이 마이크로버블을 처리한 깻잎, 상추, 미니 배추의 미생물이 $1 \sim 2 \log \mathrm{CFU} / \mathrm{g}$ 의 감소효과가 있음을 보고한 결과와 유사하였으며 Lee 등(7) 이 보고한 마이크로버블을 처리한 상추의 일반세균수가 $1 \log \mathrm{CFU} / \mathrm{g}$ 의 감소 효과를 나타낸다는 실험 결과와 유사하 였다. 따라서 $\mathrm{OMH}$ 를 이용한 세척은 침지, 오존 처리에 의한 세척과 비교하여 화학적 처리가 없었음에도 불구하고 일반세균수, 진균수, 장내세균수, 대장균군수 등에서 1 2 
$\log \mathrm{CFU} / \mathrm{g}$ 의 감소 효과를 보여 효과적인 세척 방법임을 확인하였다. Park 등(22)은 전처리 연근의 저장 및 가공 공정에서 미생물의 혼입을 완전히 제어시킬 수 없으므로 초기 미생물의 오염을 감소시키는 것이 중요하다고 보고하 였다. 따라서 저장 초기 미생물 수를 감소시킬 수 있는 세척 방법의 선택은 도라지의 저장 기간 연장에 매우 중요하다고 판단된다. 본 결과와 같이 표면 세척이 어려운 근채류에서 마이크로버블을 이용한 세척은 표면 미생물 감소를 통하여 선도 연장에 긍정적인 영향을 미칠 수 있을 것으로 판단된 다.

\section{$\mathrm{MAP}$ 에 의한 미생물학적 품질 특성}

신선편이 근채류는 박피, 세척, 절단된 형태로 진공포장 또는 일반 랩포장 되어 판매되고 있다. 따라서 본 연구에서 는 시판되는 도라지와 동일한 처리방법으로서 침지 후 polypropylene 필름 포장(Control)과 마이크로버블-열수처 리 후 $\mathrm{MAP}(\mathrm{OMH}-\mathrm{MAP})$ 포장한 세절 도라지의 저장 중 미생물학적 품질 변화를 비교하였다(Table 2). 국내에서 마 이크로버블을 이용한 품질 변화에 대한 연구는 일반적으로 마이크로버블 세척 후 일반 포장 또는 진공포장에 따른 저장 중 품질 변화를 구명하였으나 $(7,23)$ 진공포장은 유통 과정 중 진공 풀림 현상이 발생할 수 있고 절단 과정에 의하여 호흡량이 급증하는 도라지의 특성상 이와 같은 점을 고려하여 신선도를 유지할 수 있는 품목별 적정한 기체 조성을 갖는 MA 포장조건이 필요하다. 일반적으로 신선편 이 과일과 채소에 대한 MAP 기체조성은 2 5\% 산소 및 $3 \sim 8 \%$ 이산화탄소 농도로 사용된다(24). 그러나 산소 농도 가 낮으면 세절 도라지의 호흡에 의하여 포장 내부 산소 농도가 $0 \%$ 에 가깝게 될 수 있고 이로 인하여 휘발성 물질의 발생과 이취가 증가하게 되므로 고산소 MAP는 포장 내부 의 산소 환경을 유지하고 작물의 호흡을 억제함으로써 에틸 렌 발생량을 감소시켜 저장성 연장에 효과가 있는 것으로
보고되어 있다(25).

저장 기간이 증가할수록 Control과 OMH-MAP 처리한 도라지의 일 반세균수는 포장 직후 $7.0 \log \mathrm{CFU} / \mathrm{g}, 5.4 \mathrm{log}$ $\mathrm{CFU} / \mathrm{g}$ 에서 저장 10 일째에 각각 $6.8 \log \mathrm{CFU} / \mathrm{g}, 5.2 \log$ $\mathrm{CFU} / \mathrm{g}$ 로 큰 변화는 확인되지 않았다. Control 처리구와 OMH-MAP 처리구 모두 진균수도 저장기간 동안 거의 비슷 한 수준을 유지하였다. 이와 같은 결과는 마이크로버블 세 척 후 일반 포장한 상추와 진공 포장한 더덕에 대하여 저장 기간 중 일반세균의 증식이 나타났다는 결과와는 다른 경향 으로 나타났다 $(7,23)$.

Control 처리구의 장내세균수는 $6.6 \log \mathrm{CFU} / \mathrm{g}$ 이었으며, 저장 기간 동안 변화가 없었으나, OMH-MAP 처리구의 장 내세균수는 저장 4 일째 $4.6 \log \mathrm{CFU} / \mathrm{g}$ 으로, 저장 10 일째에 는 $6.1 \log \mathrm{CFU} / \mathrm{g}$ 로 증가하였다(p<0.05). Control 처리구의 대장균군수는 $5.4 \log \mathrm{CFU} / \mathrm{g}$ 에서 저장 10 일째에 약 $7 \log$ $\mathrm{CFU} / \mathrm{g}$ 로 증가하였는데 이는 Control 처리구에서 저장 중 세절 도라지의 지속적인 호흡 작용에 의하여 포장 내부의 산소가 감소함에 따라 혐기성균인 대장균군이 증식할 수 있었던 것으로 판단된다. OMH-MAP 처리구의 대장균군수 는 $3.2 \log \mathrm{CFU} / \mathrm{g}$ 에서 저장 7일째에 $4.7 \log \mathrm{CFU} / \mathrm{g}$ 로, 저장 10 일째에는 $5.5 \log \mathrm{CFU} / \mathrm{g}$ 까지 증식하였다. MAP 포장에서 이산화탄소는 일반적으로 호기성 세균의 성장을 억제하고 산화적 효소 반응을 제어하여 갈변 현상을 막기 위하여 사용되는데 $(24,26)$ 본 연구에서 적용한 고산소고이산화탄 소 $\mathrm{MAP}$ 는 일반세균과 곰팡이와 같은 호기성 세균의 성장 은 억제하였으나 혐기성균에 속하는 장내세균 및 대장균군 의 증식 억제 효과는 보이지 않았고 Choi 등(23)이 보고한 마이크로버블 세척 후 진공포장한 더덕에서는 대장균군의 증식이 발생하였다는 결과와 일치하였다. 추후 이들 혐기 적 환경에서 성장 가능한 미생물을 억제하기 위한 MAP 포장 기체 조성에 대한 추가적인 연구도 필요한 것으로 나타났다.

Table 2. Changes in total viable bacterial counts (TVC), fungi, Enterobacteriaceae and coliforms in sliced root of Platycodon grandiflorum under $\operatorname{MAP}\left(50 \% \mathrm{O}_{2}+15 \% \mathrm{CO}_{2}\right)$ during storage at $5^{\circ} \mathrm{C}$ for 10 days

(unit: $\log \mathrm{CFU} / \mathrm{g}$ )

\begin{tabular}{|c|c|c|c|c|c|c|c|c|}
\hline \multirow{2}{*}{$\begin{array}{l}\text { Storage } \\
\text { time } \\
\text { (days) }\end{array}$} & \multicolumn{2}{|c|}{ TVC } & \multicolumn{2}{|c|}{ Fungi } & \multicolumn{2}{|c|}{ Enterobacteriaceae } & \multicolumn{2}{|c|}{ Coliforms } \\
\hline & Control $^{1)}$ & OMH-MAP & Control & OMH-MAP & Control & OMH-MAP & Control & OMH-MAP \\
\hline 0 & $7.0 \pm 0.04^{22.33)}$ & $5.4 \pm 0.06^{\mathrm{c}}$ & $3.8 \pm 0.04^{\mathrm{c}}$ & $1.6 \pm 0.16^{\mathrm{ab}}$ & $6.6 \pm 0.83^{\mathrm{d}}$ & $3.7 \pm 0.02^{\mathrm{a}}$ & $5.4 \pm 0.01^{\mathrm{e}}$ & $3.2 \pm 0.02^{\mathrm{a}}$ \\
\hline 4 & $7.1 \pm 0.08^{\mathrm{e}}$ & $4.7 \pm 0.07^{\mathrm{a}}$ & $3.4 \pm 0.01^{\mathrm{c}}$ & $1.6 \pm 0.09^{\mathrm{ab}}$ & $6.7 \pm 0.10^{d}$ & $4.6 \pm 0.00^{b}$ & $6.3 \pm 0.01^{g}$ & $4.0 \pm 0.01^{\mathrm{b}}$ \\
\hline 7 & $7.2 \pm 0.02^{\mathrm{e}}$ & $5.2 \pm 0.01^{\mathrm{bc}}$ & $3.5 \pm 0.03^{\mathrm{c}}$ & $1.9 \pm 0.11^{\mathrm{b}}$ & $6.4 \pm 0.19^{\mathrm{cd}}$ & $5.2 \pm 0.02^{\mathrm{b}}$ & $6.0 \pm 0.03^{\mathrm{f}}$ & $4.7 \pm 0.08^{\mathrm{c}}$ \\
\hline 9 & $7.1 \pm 0.03^{\mathrm{e}}$ & $5.1 \pm 0.12^{\mathrm{b}}$ & $3.8 \pm 0.02^{\mathrm{c}}$ & $1.4 \pm 0.55^{\mathrm{a}}$ & $5.8 \pm 0.14^{\mathrm{c}}$ & $4.7 \pm 0.04^{b}$ & $6.6 \pm 0.07^{\mathrm{h}}$ & $5.2 \pm 0.13^{\mathrm{d}}$ \\
\hline 10 & $6.8 \pm 0.10^{d}$ & $5.2 \pm 0.04^{\mathrm{bc}}$ & $3.8 \pm 0.02^{\mathrm{c}}$ & $1.9 \pm 0.09^{\mathrm{b}}$ & $6.6 \pm 0.03^{\mathrm{d}}$ & $6.1 \pm 0.03^{\mathrm{cd}}$ & $7.0 \pm 0.08^{\mathrm{i}}$ & $5.5 \pm 0.05^{\mathrm{e}}$ \\
\hline p-value & \multicolumn{2}{|c|}{0.000} & \multicolumn{2}{|c|}{0.000} & \multicolumn{2}{|c|}{0.000} & \multicolumn{2}{|c|}{0.000} \\
\hline
\end{tabular}

\footnotetext{
${ }^{1)}$ Control, polypropylene film after washing in tap water; OMH-MAP, MAP $\left(\mathrm{O}_{2} 50 \%+\mathrm{CO}_{2} 15 \%\right)$ after washing in ozone, microbubble and $55^{\circ} \mathrm{C}$ water.

${ }^{2)}$ Values are mean \pm SE.
}

3)a-i In the same row for each microorganism means followed by different superscripts are significantly different at the $p<0.05$ level. 


\section{MAP에 의한 색도 변화}

신선편이나 최소가공기술의 식품에서 변색은 매우 중요 한 품질변화 요인 중의 하나이며, 박피 도라지는 저장 유통 중에 갈변이 발생하여 관능적 품질이 낮아지는 문제점이 있다. 세척 방법과 포장 방법이 다른 도라지의 색을 Hunter value인 L값(명도), $\mathrm{a}$ 값(적색도), $\mathrm{b}$ 값(황색도)으로 평가하였 다(Table 3). 포장 직후 도라지의 L값은 70.27에서, Control 처리구의 경우 10 일 저장 후 73.59 로, OMH-MAP 처리구의 $\mathrm{L}$ 값도 10 일 저장 후 73.15 로 감소하였으나 모두 유의적인 변화는 보이지는 않았다. 저장 중 도라지의 $\mathrm{a}$ 값은 초기값 1.07 에서 Control 처리구가 9일 저장 후 0.57로, OMH-MAP 처리구는 10 일 저장 후 0.83 으로 감소하였으나 각 처리구 모두 저장기간에 따른 유의적인 차이는 없었다. 저장 중 도라지의 $\mathrm{b}$ 값은 Control 처리구와 OMH-MAP 처리구 모두 유의적으로 증가하였다. 포장 직후 7.53에서 Control 처리구 는 저장 4 일 차에 16.83 로 급격히 증가하여 황색도의 변화 폭이 커졌다. OMH-MAP 처리구는 저장 10 일 후 $\mathrm{b}$ 값이 16.65 까지 증가하여 Control 처리구의 4 일 저장 후 값과 비슷한 수준을 보여주어, 가스 치환 포장은 도라지의 갈변 현상을 억제함을 확인하였다. Choi 등(23)은 근채류인 세절 된 더덕에 마이크로버블 처리 후 진공 포장이 더덕의 갈변 을 최소화 시키며 색을 유지하는데 효과적인 것으로 보고하 였다. 미국 표준국(NBS, National Bureau of Standards)에 의하면 색도 변화가 $(\Delta \mathrm{E}) 1.5 \sim 3.0$ 일 때 감각적인 변화를 인 지할 수 있는 수준(noticeable)이며, 3.0 6.0인 경우 감각적 변화가 눈에 띄는 수준(appreciable)이라고 규정하고 있다 (27). 이 기준에 따르면, Control 처리구는 저장 4일차에 $\Delta \mathrm{E}$ 값이 9.16로 시료의 변화를 충분히 확인할 수 있는 수준 이었으며, OMH-MAP 처리구의 경우 저장 9일차에 7.42의 수치로 나타나 MAP 포장은 도라지의 색의 변화를 일반적 인 PP 포장에 비하여 약 1.5 배 지연하는 효과를 가지고 있음을 확인하였다. 따라서 세절 도라지는 $\mathrm{OMH}$ 처리 후
가스치환 포장함으로 해서 변색을 억제하였으며, 표면색도 변화로 추정한 상품성은 Control 처리구가 저장 4일 만에 상품성이 감소하는 것과 비교하여 OMH-MAP 처리구는 저장 7일까지도 표면 색도를 유지함으로써 높은 상품성을 보였다.

\section{$\mathrm{MAP}$ 에 의한 관능적 특성}

도라지의 세척과 포장 방법에 따라 저장 기간 동안 색 (color), 향(odor), 조직감(texture), 종합 기호도(overall acceptability)를 분석한 결과는 Table 4와 같다. 관능평가 점수 5점을 도라지 상품성의 한계로 보았을 때(28) '색'을 기준으로 한 Control 처리구는 저장 9일까지는 상품적 품질 의 한계 점수인 5점을 유지하였고, $\mathrm{OMH}-\mathrm{MAP}$ 처리구는 10 일 후에도 5.5점으로 전 저장 기간 동안 색에 의한 상품성 을 유지하는 것으로 확인되었다. '향'의 경우 Control 처리 구는 4일 이후 평점이 유의적으로 감소하여 7일차에는 2.8 점으로 상품성을 소실하였고, $\mathrm{OMH}-\mathrm{MAP}$ 처리구는 7일까 지는 6.5점으로 상품성이 유지되었으나 9일 후엔 4.8점으로 상품성이 감소되었다. Whitaker와 Chang 등 $(29,30)$ 에 따르 면 저장 중 갈변 현상과 이취 생성은 polyphenol oxidase, peroxidase등의 효소에 의한 산화반응에 의하여 발생하며 이것은 제품의 품질 특성에 영향을 주는 것으로 알려져 있다. ‘조직감’의 경우 Control 처리구가 7일까지는 5.5점으 로 상품성을 유지하였으나 이후 상품성을 소실하였다. OMH-MAP 처리구는 9일간 저장 후 4.9점을 나타내어 조직 감이 유지되는 것으로 확인되었다. '종합적 기호도'는 Control 처리구가 저장 4일까지 유지하였고 이후 유의적으 로 감소하여 상품적 가치가 소실된 반면, OMH-MAP 처리 구는 저장 7일차까지 6.7점으로 상품적 가치를 유지하였고 9일차에 상품적 가치를 소실하였다. Lee 등(8)은 마이크로 버블로 세척한 상추의 기호도가 손 세척구에 비하여 유의적 으로 높다고 보고하였고 본 연구 결과도 이와 유사한 경향

Table 3. Changes in Hunter $\mathrm{a}, \mathrm{b}$ and delta $\mathrm{E}$ values of sliced root of Platycodon grandiflorum during storage at $5^{\circ} \mathrm{C}$ for 10 days

\begin{tabular}{|c|c|c|c|c|c|c|c|}
\hline \multirow{2}{*}{$\begin{array}{l}\text { Color } \\
\text { values }\end{array}$} & \multirow{2}{*}{ Treatment $^{1)}$} & \multicolumn{5}{|c|}{ Storage time (days) } & \multirow{2}{*}{$\mathrm{p}$-value } \\
\hline & & 0 & 4 & 7 & 9 & 10 & \\
\hline \multirow{2}{*}{$\mathrm{L}$} & Control & $70.3 \pm 2.69^{2)}$ & $70.5 \pm 2.38$ & $71.9 \pm 2.39$ & $72.4 \pm 3.36$ & $73.6 \pm 2.63$ & \multirow{2}{*}{0.160} \\
\hline & OMH-MAP & $70.3 \pm 2.69$ & $70.8 \pm 2.87$ & $71.6 \pm 5.77$ & $72.3 \pm 3.10$ & $73.2 \pm 5.66$ & \\
\hline \multirow{2}{*}{$\mathrm{a}$} & Control & $1.1 \pm 0.88$ & $0.8 \pm 0.39$ & $0.8 \pm 0.37$ & $0.6 \pm 0.94$ & $0.5 \pm 0.23$ & \multirow{2}{*}{0.614} \\
\hline & OMH-MAP & $1.1 \pm 0.88$ & $0.8 \pm 0.37$ & $1.0 \pm 1.25$ & $0.8 \pm 1.13$ & $0.8 \pm 0.46$ & \\
\hline \multirow{2}{*}{$\mathrm{b}$} & Control & $7.5 \pm 1.36^{\mathrm{a} 3)}$ & $16.8 \pm 1.52^{\mathrm{d}}$ & $17.8 \pm 1.55^{\mathrm{d}}$ & $20.6 \pm 2.02^{\mathrm{e}}$ & $21.5 \pm 1.95^{\mathrm{e}}$ & \multirow{2}{*}{0.000} \\
\hline & OMH-MAP & $7.5 \pm 1.36^{\mathrm{a}}$ & $9.5 \pm 0.84^{b}$ & $10.6 \pm 0.97^{b}$ & $14.8 \pm 0.97^{\mathrm{c}}$ & $16.7 \pm 4.66^{d}$ & \\
\hline \multirow{2}{*}{$\triangle \mathrm{E}$} & Control & 0.0 & 9.2 & 10.2 & 13.1 & 14.2 & \\
\hline & OMH-MAP & 0.0 & 2.0 & 3.3 & 7.4 & 9.5 & \\
\hline
\end{tabular}

\footnotetext{
${ }^{1)} \mathrm{Control}$, polypropylene film packaging after washing in tap water; OMH-MAP, MAP $\left(\mathrm{O}_{2} 50 \%+\mathrm{CO}_{2} 15 \%\right)$ after washing in ozone, microbubble, and $55^{\circ} \mathrm{C}$ water. ${ }^{2)}$ Values are mean \pm SE.

3)a- In the same row and column for each parameter mean followed by different superscripts are significantly different at the $p<0.05$ level.
} 
Table 4. Sensory characteristics of sliced root of Platycodon grandiflorum during storage at $5^{\circ} \mathrm{C}$ for 10 days

\begin{tabular}{|c|c|c|c|c|c|c|}
\hline \multirow{2}{*}{ Attribute } & \multirow{2}{*}{ Treatment ${ }^{1)}$} & \multicolumn{4}{|c|}{ Storage time (days) } & \multirow{2}{*}{ p-value } \\
\hline & & 4 & 7 & 9 & 10 & \\
\hline \multirow{2}{*}{ Color } & Control & $6.5 \pm 0.9^{2) b c 3)}$ & $6.0 \pm 1.3^{\text {bcd }}$ & $5.3 \pm 1.5^{\mathrm{d}}$ & $3.8 \pm 1.2^{\mathrm{e}}$ & \multirow{2}{*}{0.000} \\
\hline & OMH-MAP & $7.8 \pm 0.7^{\mathrm{a}}$ & $6.9 \pm 1.1^{\mathrm{b}}$ & $5.6 \pm 1.7^{\mathrm{c}}$ & $5.5 \pm 0.8^{\mathrm{d}}$ & \\
\hline \multirow{2}{*}{ Flavor } & Control & $5.0 \pm 1.4^{c}$ & $2.8 \pm 1.1^{\mathrm{d}}$ & $1.8 \pm 0.8^{\mathrm{e}}$ & $1.2 \pm 0.4^{\mathrm{e}}$ & \multirow{2}{*}{0.000} \\
\hline & OMH-MAP & $7.7 \pm 1.2^{\mathrm{a}}$ & $6.5 \pm 1.0^{\mathrm{b}}$ & $4.8 \pm 0.9^{c}$ & $3.1 \pm 1.8^{\mathrm{d}}$ & \\
\hline \multirow{2}{*}{ Texture } & Control & $6.8 \pm 1.1^{b}$ & $5.5 \pm 1.6^{\mathrm{c}}$ & $3.3 \pm 1.8^{\mathrm{d}}$ & $3.8 \pm 1.8^{\mathrm{d}}$ & \multirow{2}{*}{0.000} \\
\hline & OMH-MAP & $8.0 \pm 0.7^{\mathrm{a}}$ & $6.8 \pm 1.1^{\mathrm{b}}$ & $4.9 \pm 0.9^{c}$ & $4.8 \pm 1.1^{\mathrm{c}}$ & \\
\hline \multirow{2}{*}{ Overall acceptability } & Control & $5.8 \pm 1.4^{\mathrm{c}}$ & $3.3 \pm 1.2^{\mathrm{e}}$ & $1.6 \pm 0.7^{\mathrm{f}}$ & $1.2 \pm 0.4^{\mathrm{f}}$ & \multirow{2}{*}{0.000} \\
\hline & OMH-MAP & $7.8 \pm 0.7^{\mathrm{a}}$ & $6.7 \pm 0.9^{b}$ & $4.3 \pm 0.5^{\mathrm{d}}$ & $3.1 \pm 1.6^{\mathrm{e}}$ & \\
\hline
\end{tabular}

${ }^{11)}$ Control, polypropylene film packaging after washing in tap water; OMH-MAP, MAP $\left(\mathrm{O}_{2} 50 \%+\mathrm{CO}_{2} 15 \%\right)$ after washing in ozone, microbubble, and $55^{\circ} \mathrm{C}$ water.

${ }^{2)}$ Values are mean $\pm \mathrm{SE}$.

3)a In the same row and column means followed by different superscripts are significantly different at the $p<0.05$ level.

Table 5. Correlation coefficients between quality and sensory characteristics of sliced root of Platycodon grandiflorum

\begin{tabular}{|c|c|c|c|c|c|c|c|c|c|c|c|c|}
\hline \multirow{2}{*}{ Treatment ${ }^{1)}$} & & \multirow{2}{*}{ TVC } & \multirow{2}{*}{ Fungi } & \multirow{2}{*}{$\begin{array}{c}\text { Entero- } \\
\text { bacteriaceae }\end{array}$} & \multirow{2}{*}{ Coliforms } & \multirow{2}{*}{$\begin{array}{c}\text { Overall } \\
\text { acceptability }\end{array}$} & \multicolumn{3}{|c|}{ Hunter's values } & \multicolumn{3}{|c|}{ Sensory factors } \\
\hline & & & & & & & $\mathrm{L}$ & a & $\mathrm{b}$ & Texture & Color & Flavor \\
\hline \multirow{11}{*}{ Control } & TVC & 1 & $.942^{* * 2)}$ & $.903^{* *}$ & $.869^{* *}$ & -.085 & $.583^{*}$ & $-.770^{* *}$ & .465 & .466 & .151 & -.063 \\
\hline & Fungi & & 1 & $.897^{* *}$ & $.895^{* *}$ & -.040 & $.730^{* *}$ & $-.751^{* *}$ & .427 & -.307 & -.312 & -.092 \\
\hline & Enterobacteriaceae & & & 1 & $.824^{* *}$ & .113 & $.686^{*}$ & $-.609^{*}$ & .390 & -.229 & .157 & .201 \\
\hline & Coliforms & & & & 1 & .190 & $.718^{* *}$ & $-899^{* *}$ & $.763^{* *}$ & -.309 & -.232 & .244 \\
\hline & Overall acceptability & & & & & 1 & -.167 & -.189 & $-.506^{* *}$ & $.599^{* *}$ & $.560^{* *}$ & $.877^{* *}$ \\
\hline & $\mathrm{L}$ & & & & & & 1 & $-.331^{* *}$ & $.338^{* *}$ & -.192 & -.263 & -.167 \\
\hline & $\mathrm{a}$ & & & & & & & 1 & $-.286^{*}$ & -.085 & -.002 & -.251 \\
\hline & $\mathrm{b}$ & & & & & & & & 1 & $-.480^{* *}$ & $-.313^{*}$ & $-.346^{*}$ \\
\hline & Texture & & & & & & & & & 1 & $.543^{* *}$ & $.495^{* *}$ \\
\hline & Color & & & & & & & & & & 1 & $.556^{* *}$ \\
\hline & Flavor & & & & & & & & & & & 1 \\
\hline \multirow{11}{*}{ OMH-MAP } & TVC & 1 & .290 & .654 & $.783^{*}$ & -.448 & .198 & -.217 & .357 & -.536 & -.527 & -.395 \\
\hline & Fungi & & 1 & .498 & .183 & .395 & -.125 & .577 & -.575 & .220 & .106 & .397 \\
\hline & Enterobacteriaceae & & & 1 & .694 & .116 & .010 & .165 & -.058 & -.004 & -.051 & .156 \\
\hline & Coliforms & & & & 1 & $-.898^{*}$ & .365 & -.369 & .567 & $-.944^{* *}$ & $-.917^{*}$ & $-.867^{*}$ \\
\hline & Overall acceptability & & & & & 1 & .061 & -.081 & $-.465^{* *}$ & $.773^{* *}$ & $.744^{* *}$ & $.971^{* *}$ \\
\hline & $\mathrm{L}$ & & & & & & 1 & $-.518^{* *}$ & $.366^{* *}$ & -.025 & -.034 & .093 \\
\hline & a & & & & & & & 1 & -.046 & -.015 & -.114 & -.052 \\
\hline & $\mathrm{b}$ & & & & & & & & 1 & $-.340^{*}$ & $-.525^{* *}$ & $-.432^{* *}$ \\
\hline & Texture & & & & & & & & & 1 & $.691^{* *}$ & $.727^{* *}$ \\
\hline & Color & & & & & & & & & & 1 & $.743^{* *}$ \\
\hline & Flavor & & & & & & & & & & & 1 \\
\hline
\end{tabular}

${ }^{1)}$ Control, polypropylene film packaging after washing in tap water; OMH-MAP, MAP $\left(\mathrm{O}_{2} 50 \%+\mathrm{CO}_{2} 15 \%\right)$ after washing in ozone, microbubble, and $55^{\circ} \mathrm{C}$ water. $\left.{ }^{2}\right)^{*}, \mathrm{p}$-value $<0.05 ;{ }^{* *}, \mathrm{p}$-value $<0.01$. 
을 보임에 따라 세절 도라지는 마이크로버블로 세척 후 MAP 포장하여 유통하는 것이 관능적 품질 유지에 효과적 인 것으로 판단된다.

\section{상관관계 및 품질 지표 선정}

도라지의 저장 중 품질을 예측할 수 있는 적정 품질 지표 를 선정하기 위하여 각 품질 특성 간의 상관관계를 분석한 결과는 Table 5과 같다. 종합적인 기호도는 Control 처리구 와 OMH-MAP 처리구 모두 Hunter b값과는 부(-)의 상관관 계를 보여 저장 기간 동안 황색도가 낮을수록 종합적인 기호도가 증가하는 것으로 나타났고 조직감, 색, 향과는 정 $(+)$ 의 관계로 영향을 주는 것으로 나타났다 $(\mathrm{p}<0.05)$.

종합적 기호도는 Control 처리구와 OMH-MAP 처리구 모두 향과 높은 상관성을 보이는 것으로 분석되었다. Control 처리구에서는 대장균군이 증가할수록 $\mathrm{L}$ 값, $\mathrm{b}$ 값이 증가하는 정의 관계를 나타냈고 적색도인 $\mathrm{a}$ 값은 감소하는 경향을 보였다. 하지만 OMH-MAP 처리구에서 대장균군의 증가는 종합적인 기호도, 조직감, 색, 향 등의 관능적 품질 요인과 부의 상관관계를 보여 대장균군의 증가는 조직감, 색, 향, 종합적 기호도의 감소에 영향을 주는 것으로 평가되 었다.

이상의 결과를 토대로 종합적 기호도에 영향을 미치는 4 가지의 품질 인자(색, 향, 조직감, 대장균군)와의 관계를 회귀분석한 결과는 Table 6과 같다. 종합적 기호도와 색, 조직감은 Control 처리구와 OMH-MAP 처리구 모두가 결정 계수 $\left(\mathrm{R}^{2}\right) 0.60$ 이하로 상관도가 낮았다. 그러나 종합적 기호 도와 향의 상관도를 분석한 결과 Control 처리구는 $\mathrm{R}^{2}=0.76$, $\mathrm{OMH}-\mathrm{MAP}$ 처리구는 $\mathrm{R}^{2}=0.94$ 으로 높은 선형을 가지는 $\mathrm{y}=0.886 \mathrm{x}+0.438, \mathrm{y}=0.938 \mathrm{x}+0.061$ 의 선형 회귀식이 산출되 었다. 저장 기간 중 세절 도라지의 종합적 기호도는 향만으 로도 각각 전체 모형의 $76,94 \%$ 를 설명하였으며, 향이 1 단 위씩 증가하면 Control 도라지의 종합적 기호도는 0.886

Table 6. Regression equations and coefficients of determination between physicochemical properties and acceptability of sliced root of Platycodon grandiflorum during storage at $5^{\circ} \mathrm{C}$ for 10 days

\begin{tabular}{ccccc}
\hline Response & Treatment $^{1)}$ & Regression equation & $\mathrm{R}^{2}$ & $\mathrm{p}$-value \\
\hline \multirow{2}{*}{ Color } & Control & $\mathrm{y}=0.452 \mathrm{x}+4.010$ & 0.300 & 0.000 \\
& OMH-MAP & $\mathrm{y}=0.453 \mathrm{x}+4.042$ & 0.544 & 0.000 \\
\hline \multirow{2}{*}{ Flavor } & Control & $\mathrm{y}=0.886 \mathrm{x}+0.438$ & 0.764 & 0.000 \\
& OMH-MAP & $\mathrm{y}=0.938 \mathrm{x}+0.061$ & 0.941 & 0.000 \\
\hline \multirow{2}{*}{ Texture } & Control & $\mathrm{y}=0.486 \mathrm{x}+3.491$ & 0.764 & 0.764 \\
& OMH-MAP & $\mathrm{y}=0.647 \mathrm{x}+2.811$ & 0.589 & 0.000 \\
\hline \multirow{2}{*}{ Coliforms } & Control & $\mathrm{y}=0.063 \mathrm{x}+6.215$ & 0.036 & 0.653 \\
& OMH-MAP & $\mathrm{y}=-0.149 \mathrm{x}+5.406$ & 0.757 & 0.015 \\
\hline
\end{tabular}

${ }^{1)}$ Control, polypropylene film packaging after washing in tap water for $3 \mathrm{~min}$; OMH-MAP, MAP $\left(\mathrm{O}_{2} 50 \%+\mathrm{CO}_{2} 15 \%\right)$ after washing in ozone, microbubble, and $55^{\circ} \mathrm{C}$ water.
증가하고 $\mathrm{OMH}-\mathrm{MAP}$ 도라지의 기호도는 0.938 증가하는 것으로 나타났다. 또한 $\mathrm{OMH}-\mathrm{MAP}$ 도라지에서 대장균군은 종합적 기호도와 $\mathrm{R}^{2}=0.757$ 로 높은 선형을 가지는 $\mathrm{y}=-0.149 \mathrm{x}$ +5.406 의 선형 회귀식이 산출되어 저장 기간 중 도라지의 종합적 기호도는 대장균군으로 약 $75 \%$ 가 설명되는 것으로 나타났으며 대장균군이 1 단위 증가하면 도라지의 기호도 는 0.149 감소하는 것으로 나타났다. 따라서 본 연구에서 실시한 세척과 포장 방법에 따라 도라지를 저장할 경우 향과 대장균군의 품질 인자를 통해 도라지의 종합적 기호도 예측이 가능한 것으로 나타났다.

\section{요 약}

세절 도라지의 선도 연장을 위한 연구로 세절 도라지를 마이크로버블을 처리함과 동시에 $55^{\circ} \mathrm{C}$ 물에 열수처리하고 저장 기간 연장을 조사하기 위하여 고산소고이산화탄소 $\mathrm{MAP}$ 를 처리한 후 10 일간 저장하면서 미생물수, 색상 및 관능적 품질 변화를 조사하였다. 마이크로버블-열수처리 는 세절 도라지의 일반세균수, 진균류수, 장내세균수, 대장 균군수의 감소를 보였으며 특히 장내세균수와 대장균군수 는 $2 \log \mathrm{CFU} / \mathrm{g}$ 이상의 감소 효과를 나타냄으로써 미생물 제어 효과가 뚜렷이 나타났다. 저장 중 고산소고이산화탄 소 MAP 포장은 호기성균의 성장은 억제하는 것으로 나타 났으나 혐기성균에 속하는 장내세균과 대장균군은 저장 기간이 증가할수록 증식하는 것으로 확인되었다. 시판 도 라지와 동일한 방법으로서 침지 후 PP 포장한 세절 도라지 와 본 연구에서 제안한 $\mathrm{OMH}$ 처리 후 고산소고이산화탄소 MAP 처리한 세절 도라지의 저장 중 표면 색도를 분석한 결과 황색도 $\mathrm{b}$ 값이 유의적인 변화를 보여주었으며 $\mathrm{OMH}-$ $\mathrm{MAP}$ 처리한 세절 도라지의 $\mathrm{b}$ 값은 저장 10 일째의 수준이 일반 포장 도라지의 4일째 수준과 유사하였다. 또한 관능적 평가에서, OMH-MAP 처리한 세절 도라지에 대한 관능적 평가에서 향과 종합적 기호도의 변화는 Control 처리구 보 다 낮아 품질의 신선도가 기존의 세절 도라지 세척 및 포장 방법과 비교하여 3일 이상 연장됨을 확인하였다. 이상의 품질 변화 특징을 종합하여 $5^{\circ} \mathrm{C}$ 에서 저장한 세절 도라지의 기호도와 가장 높은 상관관계를 가지는 인자를 분석한 결 과, 향과 대장균군이 가장 높은 상관도를 보였고 $\mathrm{OMH}-$ MAP 처리한 세절 도라지의 기호도는 향과 대장균군으로 전체 모형의 $94 \%$ 와 $76 \%$ 를 설명할 수 있었다. 결론적으로 마이크로버블-열수 세척을 하여 세절 도라지를 고산소/고 이산화탄소 MAP 포장하는 것이 세절 도라지의 저장유통 중 품질 유지에 효과적임을 확인할 수 있었다.

\section{감사의 글}

본 논문은 농림축산식품부의 재원으로 농림수산식품기 
술기획평가원의 고부가가치식품기술개발사업의 지원과 한국식품연구원의 지원을 받아 수행된 연구로 이에 감사드 립니다.

\section{References}

1. Lee MJ (2008) A feasibility study of using preprocessed and fresh-cut vegetables for school food services in Gyeong-Gi province. Ph D Thesis, Dankook University, Korea, p 1-3

2. Kim SJ, Sun SH, Min KJ, Yoon KS (2011) Microbiological hazard analysis and verification of critical control point (CCP) in a fresh-cut produce processing plant: case study of a fresh-cut leaf processing plant. J East Asian Soc Dietary Life, 21, 392-400

3. Lee SJ, Lee SM (2006) Survey on the use of pre-processed food materials in school food services in the Kyunggi area. Korea J Food Cookery Sci, 23, 553-564

4. Park SH, Noh BY, Han KJ (2012) Standardization of manufacturing process and storage condition for pre-processed foodstuffs (pre-processed Namul: peeled balloon flower roots and parboiled bracken). J Korean Soc Food Sci Nutr, 41, 1611-1618

5. Kwak SJ, Park NY, Kim GC, Kim HR, Yoon KS (2012) Changes in quality characteristics of wild root vegetables during storage. J Korean Soc Food Sci Nutr, 41, 1158-1167

6. Choi DJ, Kim CB, Lee SH, Yoon JT, Choi BS, Kim HK (2000) Effects of precooling and packaging film materials on quality of water dropwort (Oenanthe stolonifera DC.) at low temperature storage. J Kor Soc Hort Sci, 41, 379-382

7. Lee SA, Youn AR, Kwon KH, Kim BS, Cha HS (2009) Washing effect of micro-bubbles and changes in quality of lettuce (Lactuca sativa L.) during storage. Korean J Food Preserv, 16, 321-326

8. Kim SJ, Sun SH, Kim GC, Kim HR, Yoon KS (2011) Quality changes of fresh-cut leafy and condiment vegetables during refrigerated storage. J Korean Soc Food Sci Nutr, 40, 1141-1149

9. Lee GD, Joo GJ, Kwon JH (2000) Optimization for roast flavour formation of Platycodon grandiflorum tea. J Korean Soc Food Sci Nutr, 29, 752-757

10. Ahvenainen R (1996) New approaches in improving the shelf life of minimally processed fruit and vegetables. Trends in Food Sci Technol, 7, 179-187
11. Park JN, Kyoung JH, Jeong CS (2011) Optimum gas ratio and packaging films for active MA Packaging of cut red cabbage. J Agr Life Environ Sci, 23, 11-15

12. Cha HS (2009) Present state and future prospect for microbubble technology. Bulletin of Food Technol, 22, 544-552

13. Lee WJ, Lee CH, Yoo JY, Kim KY, Jang KI (2011) Sterilization efficacy of washing method using based on microbubbles and electrolyzed water on various vegetables. J Korean Soc Food Sci Nutr, 40, 912-917

14. Park JH, Hong SI, Jeong MC, Kim DM (2013) Effect of mild heat and organic acid treatments on the quality of fresh-cut lotus roots. Korean J Food Preserv, 20, 23-29

15. Lee SC, Kim SY, Choi SJ, Lee IS, Jung MY, Yang SM, Chae HJ (2010) Effect of soaking and heat treatment conditions on physicochemical and organoleptic quality of lotus root. Korean J Food Sci Technol, 42, 45-49

16. KFDA (2014) Food code. Korea Food and Drug Administration, Korea

17. Cho MH, Bae EK, Ha SD, Park YS, Mok CK, Hong KP, Kim SP, Park JY (2005) Evaluation of dry rehydratable film method for enumeration of microorganisms in meat, dairy and fishery products. Korean J Food Sci Technol, 37, 294-300

18. Cheon JY, Yang JH, Kim MJ, Lee SM, Cha MH, Park KH, Ryu K (2012) Microbial hazard analysis of manufacturing processes for starch noodle. J Food Hyg Saf, 27, 420-426

19. Health Protection Agency (2010) Identification of Enterobacteriaceae. National Standard Method BSOPID, 16, $1-16$

20. European Union Regulation (2005) Commission Regulation (EC) No. 2073/2005 of 15 November 2005 on Microbiological criteria for foodstuffs. Off J Eur Union, L338, 1-26

21. KFDA (2009) Food code. Korea Food and Drug Administration, Korea

22. Park KJ, Jeong JW, Lim JH, Kim BK, Jeong SW (2008) Quality changes in peeled lotus roots immersed in electrolyzed water prior to wrap and vacuum-packaging. Korean J Food Preserv, 15, 622-629

23. Choi DJ, Lee YJ, Kim YK, Kim MH, Choi SR, Cha HS, Youn AR (2013) Effect of washing methods on the quality of freshly cut sliced Deodeok (Codonopsis lanceolata) during storage. Korean J Food Preserv, 20, 751-759

24. Kang DH (2012) Current thermal/non-thermal technologies 
to control foodborne pathogens, Food Science and Industry, 45, 48-59

25. Liu Z, Wang X, Zhu J, Wang J (2010) Effect of high oxygen modified atmosphere on postharvest physiology and sensorial qualities of mushroom. Int $\mathrm{J}$ Food Sci Technol, 45, 1097-1103

26. Rai DR, Paul S (2007) Packaging requirements of highly respiring produce under modified atmosphere: a review. J Food Sci Technol, 44, 10-15

27. Han EL (1991) Numerical principle of food colder (II). Food Technol, 4, 41-46
28. Jordan JL, Shewfelt RL, Prussia SE, Hurst WC (1985) Estimating the price of quality characteristics for tomatoes: aiding the evaluation of the postharvest system. Hort Sci, 20, 203-205

29. Whitaker JR, Lee CY (1995) Enzymatic browning and its prevention. ACS symposium series. American Chemical Society, Washington, USA, p 2-7

30. Chang MS, Kim JG, Kim GH (2011) Quality characteristics of fresh-cut lotus roots according to the temperature of the wash water. Korean J Food Preserv, 18, 288-293 